\title{
Binalarda Enerji Verimliliği Kapsamında Yapılan Projelerin Değerlendirilmesi: Türkiye Örneği
}

\author{
Özlem AYDIN ${ }^{1 \star}$
}

\section{Öz}

Ülkemiz, enerjide büyük oranda dışa bağımlı bir ülke olarak tükettiği enerjinin büyük bölümünü ithal etmektedir. Bu olumsuz durumun iyileştirilmesi için son yıllarda yenilenebilir enerji kaynaklarının etkin kullanımı ve enerji verimliliği konularında ciddi çalışmalar yapılmaktadır. Bu konuda ülkemizde 2007 yılında yürürlüğe giren Enerji Verimliliği Kanunu ile birlikte enerjinin etkin kullanımı, israfın önlenmesi, enerji maliyetlerinin ekonominin üzerindeki yükünün hafifletilmesi ve çevrenin korunması için enerji kaynaklarının verimliliğinin arttırılması yönünde projeler gerçekleştirilmektedir.

Yapılan bu çalışmada; Türkiye'de artan enerji ihtiyacına bağlı olarak enerji tüketiminin azaltılması ve enerji yönetim bilincinin resmi kurumlarda ve özel sektörde artırılması için yapılan çalışmalar değerlendirilmiştir. Bu kapsamda binalarda enerji verimliliğinin artırılması amacı ile kamu kurumlarının, yerel yönetimlerin ve $A B$ üyesi ülkelerin paydaş olarak yer aldığı 6 proje incelenmiştir. Projelerin amacı, kapsamı, yapılan çalışmalar ve sonuçları değerlendirilerek analizleri yapılmıştır. Yönetmelikler dikkate alınarak kurumların ve özel sektörün mevcut ve yeni binalarda enerji verimliliği çalışmalarına önem vermesi binalarda enerji tüketimini azaltacaktır. Uygulanan projelerin Türkiye'nin enerji tablosuna olumlu anlamda katkı sağlaması, enerji yönetim mekanizmalarının ve eğitim faaliyetlerinin sürekliliği açısından oldukça önemlidir.

Anahtar Kelimeler: Enerji tüketimi, enerji tasarrufu, binalarda enerji verimliliği, proje.

\section{Evaluation of Projects in the Scope of Building Energy Efficiency: The Case of Turkey}

\begin{abstract}
Our country imports a large part of the energy it consumes as a country dependent on foreign energy. In order to improve this situation, serious efforts have been made in recent years on the efficient use of renewable energy sources and energy efficiency. In this regard, many studies have been carried out in order to increase the efficiency of energy resources for the efficient use of energy, to prevent waste, to reduce the burden of energy costs on the economy and to protect the environment with the Energy Efficiency Law, which came into force in 2007 in our country.
\end{abstract}

In this study; Depending on the reduction of energy consumption in Turkey's growing energy needs and energy management awareness among the public institutions and the private sector to increase the studies were evaluated. In this context, 6 projects involving public institutions, local administrations and EU member countries as stakeholders to increase energy efficiency in buildings were examined. The aim, scope, studies and results of the projects were evaluated and analyzed. Considering the regulations, the fact that institutions and private sector attach importance to energy efficiency studies in existing and new buildings will reduce energy consumption in buildings. Implementation of the projects, to contribute in a positive sense in Turkey's energy table, the mechanism of energy management and training activities is very important in terms of continuity.

Key Words: Energy consumption, energy saving, energy efficiency in buildings, project

\footnotetext{
${ }^{1}$ Karadeniz Teknik Üniversitesi, Mimarlık Fakültesi, Mimarlık Bölümü, Trabzon, Türkiye.

* Corresponding author: ozlem.aydin@ktu.edu.tr,

Gönderim Tarihi: 11.01.2019

Kabul Tarihi: 26.06.2019
} 


\section{GiRiş}

Dünya'da ve ülkemizde enerji intiyacı her geçen gün artmaktadır. Artan bu talebe karşı enerjinin verimli kullanımı ve alternatif enerji kaynakları konusunda çalışmalar yapılmaktadır. Enerji kaynaklarının yapılarda kullanımından önce bu kaynakların elde edilmesi ve üretimi aşamasında enerji kullanımı başlamaktadır. Bu noktada tüketilen enerjinin denetlenmesi ve ekosisteme verdiği zararı minimuma indirmek için enerji korunumu ve alternatif enerji stratejileri geliştirilmelidir.

Enerji özellikle 20. yüzyılın başlarından itibaren ülkelerin rekabet üstünlüğü sağlamasında yararlandıkları en önemli unsurlardan biri olmuştur. 21. yüzyılda ise dünyadaki teknolojik yenilikler, uluslararası sınırların geçirgenliğinin artması, sermaye hareketleri için sınırların hemen hemen kalkmış olması ve iletişim alanındaki gelişmeler hem dünyadaki enerji kullanım miktarını arttırmış hem de enerjiyi üzerinde çalışmalar yapılması, politikalar belirlenmesi gereken bir konu haline getirmiştir (Kavak, 2005,s.5).

Enerjinin tüketim alanı temelde sanayi, ulaşım ve bina olarak üç büyük sektörde gerçekleşmektedir (Al-Homoud, 2001). Enerjinin büyük bir bölümü binaların yapım ve kullanımında tüketildiğinden, tüm dünyada bina sektöründeki enerji tasarrufu potansiyeli oldukça büyüktür. Birçok ülke bu potansiyelden yararlanmak üzere ilgili yasal mevzuatlarını geliştirmektedir. Avrupa'da da enerji tüketiminin \%40'ı binalardan kaynaklanmaktadır (Directive EU,2010). Bu nedenle, binalar için enerji performansı gereksinimlerinin belirlenmesi, binalara enerji kimlik belgelerinin verilmesi ve binalarda enerji verimliliğinin teşvik edilmesi amacıyla Avrupa Parlamentosu tarafından 2002 yılında 2002/91/EC sayılı Binalarda Enerji Performansı Direktifi yayımlanmıştır (Directive EC, 2002). Bu direktif daha sonra ekonomi ve enerjideki talepler dikkate alınarak 2010 yılında revize edilerek EPBD-Recast olarak yayımlanmıştır. EPBDRecast içeriğinde, bina enerji verimliliğinde maliyet etkinliğini de ön plana çıkaracak maliyet optimum enerji verimliliği ve yaklaşık sıfır enerjili bina kavramları yer almaktadır. Revize edilen direktife göre tüm $A B$ üyesi ülkeler kendi ulusal koşullarına uygun hesaplama yöntemi geliştirmeleri ve bu yöntemle binalarda enerji performans gereksinimlerinin optimum maliyet düzeylerini belirlemeleri zorunludur. Ayrıca bu ülkeler 2020 yılı sonu itibari ile tüm yeni binaların yaklaşık sıfır enerjili bina olmasını sağlamakla yükümlüdürler (Sağlam, Yılmaz, 2015, s.1268).

Avrupa Birliği'nde enerji konusunda bu gelişmeler yaşanırken ülkemizde ulusal politikalarımız arasında yer alan enerji ithalatının yükünü aşağı çekmek için enerji verimliliği konusunda önemli projeler gerçekleştirmektedir. Bu konuda Türkiye'de ilk planlı enerji tasarrufu çalışmaları, 1981 yılında Elektrik İşleri Etüd (EIE) İdaresi Genel Müdürlüğü'nce başlatılmıştır. Bu çalışmaların yurt genelinde daha etkili ve kapsamlı yürütülmesi amacıyla 1992 yılı sonunda EIE bünyesinde Ulusal Enerji Tasarrufu Merkezi (UETM) oluşturulmuştur (Demircan, Uçak, 2009,s.3). Daha sonra 2004 yılında Onuncu Kalkınma Planının bir parçası olarak Enerji Verimliliğini Geliştirme Planı kabul edilmiştir. Bu plan; seçilen sektörlerdeki ve alanlardaki enerji verimliliğini arttıracak eylemlerin uygulanmasını; çeşitli mevcut uygulamaların genişletilmesini; kamuoyunun bilinçlendirilmesini ve sonuç olarak talep yönetimine katkıda bulunmak için örnek verilebilecek uygulamaların yayılmasını hedeflemektedir. Türkiye, son yıllarda enerji verimliliği alanında kaydettiği ilerlemelere rağmen, gelişmiş ülkelere kıyasla "enerji yoğun" ekonomilerden biridir. Uluslararası Enerji Ajansı (IEA) ve Eurostat verilerine göre, ülkemizde enerji yoğunluğu $O E C D$ ve $A B-27$ ortalamalarının üzerindedir ve dolayısıyla enerji yoğunluğunun azaltılması ve enerji verimliliği sektöründe iyileştirmelerde bulunulması önemlidir (Şekil 1). Bu kapsamda gerçekleştirilen enerji 
verimliliği stratejileri ile 2023 yılına kadar enerji yoğunluğunun en az yüzde 20 oranında azaltılması hedeflenmiştir (Resmi Gazete, 2013).

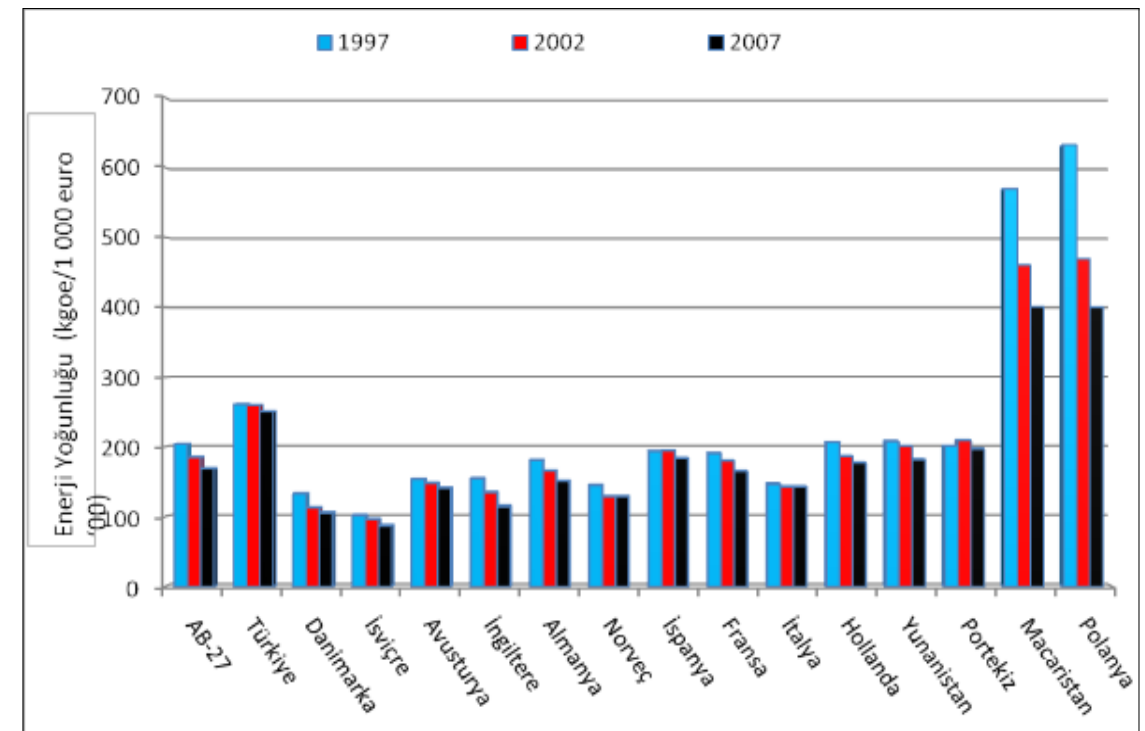

Şekil 1.Türkiye'nin Enerji Yoğunluğunun Bazı Avrupa Ülkeleri İle Karşılaştırılması (Keskin, 2011)

Enerji verimliliği alanında çıkarılan en kapsamlı yasal düzenleme 02.05.2007 tarih ve 26510 sayılı Resmi Gazetede yayımlanarak yürürlüğe giren 5627 sayılı Enerji Verimliliği Kanunu'dur. Kanunun amacı enerjinin etkin kullanılması, israfın önlenmesi, enerji maliyetlerinin ekonomi üzerindeki yükünün hafifletilmesi ve çevrenin korunması için enerji kaynaklarının ve enerjinin kullanımında verimliliğinin arttırılmasıdır (5627 EVK,2007). Söz konusu kanunun yürürlüğe girmesinden sonra, ilgili bakanlıklar tarafından çok sayıda yönetmelik, genelge, tebliğ yayımlanarak Türkiye'nin enerji verimliliği mevzuat çerçevesi oluşturulmuştur.

Binalarda enerji verimliliğine ilişkin mevzuatta yer alan kanun ve yönetmelikler:

- 5627 Sayılı Enerji Verimliliği Kanunu

- Enerji Kaynaklarının ve Enerjinin Kullanımında Verimliliğin Arttııımasına Dair Yönetmelik

- Binalarda Enerji Performansı Yönetmeliği

- Merkezi Isıtma ve Sıhhi Sıcak Su Sistemlerinde Isınma ve Sıhhi Sıcak Su Giderlerinin Paylaştırılmasına İlişkin Yönetmelik

Artan nüfus artışı ile binalardaki enerji tüketimleri de her geçen gün artmaktadır. Genel olarak bu artışı azaltmak ve enerjiyi verimli kullanmak adına Enerji Verimliliği Kanunu kapsamında çeşitli yasal önlemler alınmaya başlanmış ve buna paralel olarak $A B$ yasaları uyum sürecinde AB'nin 2002/91/EC sayılı Binalarda Enerji Performansı Direktifi temel alınarak Binalarda Enerji Performansı Yönetmeliği (BEP Yönetmeliği) hazırlanmıştır. Binaların enerji performanslarını değerlendiren bu yönetmelik, 05.12.2008 tarihinde Resmi Gazetede yayımlanmış, bir yıl sonra da 05.12.2009 tarihinde yürürlüğe girmiştir. BEP Yönetmeliği ile binalarda ısıtmanın dışında soğutma havalandırma, aydınlatma ve sıcak su temini gibi enerji kullanım alanları ve sistemlerinin verimlilikleri de dikkate alınmaya başlanmıştır. Yönetmelik gereğince binaların enerji performanslarının " $A$ " ile " $G$ " sınıfları arasında etiketlenmesi suretiyle enerji tüketimi ve sera gazı emisyonları açısından belgelendirilmesi çalışmaları başlamıştır. Ayrıca mevcut binaların enerji performanslarının da yükseltilmesi ve enerji kimlik belgelerinin oluşturularak enerji tüketimiyle sera gazı emisyonları açısından 2017 
yılı sonuna kadar bütün binaların etiketlenmesi öngörülmüştür. Enerjide arz güvenliğinin sağlanması, dışa bağımlılıktan kaynaklanan risklerin azaltılması, enerji maliyetlerinin sürdürülebilir kılınması, iklim değişikliğiyle etkin mücadele ve çevrenin korunması bakımından enerji verimliliği konusu her geçen gün önemini artırmaktadır. $\mathrm{Bu}$ açıdan enerjinin üretimi, iletimi ve tüketimi aşamalarında verimliliğin sağlanması, bilinçsiz kullanım ve israfın önlenmesi, sektörel ve makro düzeyde enerji yoğunluğunun azaltılması Türkiye'nin enerji alanındaki temel politikalarından biri olmalıdır (Doğan, Yılankıran, 2015, s. 383).

Avrupa Birliği'ne uyum sürecinde enerji konusunda gerçekleştirilen yasal düzenlemeler çerçevesinde mevzuat ve politikaların geliştirilmesi için kamuoyunda enerji performansı açısından bütüncül tasarım yaklaşımının tanıtılması ve bu konularda bilgi ve bilinç düzeyinin iyileştirilmesi konusunda çalışmalar yapılmaktadır. Bu bağlamda 2020 yılı enerji verimliliği $A B$ hedefleri dikkate alındığında ülkemizde de bu konuda yapılan proje çalışmalarında özellikle bina, sanayi ve ulaşım alanında enerji tasarruf hedefleri belirlenmiştir (Şekil 2). Bu çerçevede enerji verimliliğini iyileştirmeye yönelik çalışmalar yürütülmesi, mevcut bazı uygulamaların yaygınlaştırılması, örnek uygulamaların duyurularak kamuoyu bilincinin yükseltilmesi amaçlanmaktadır.

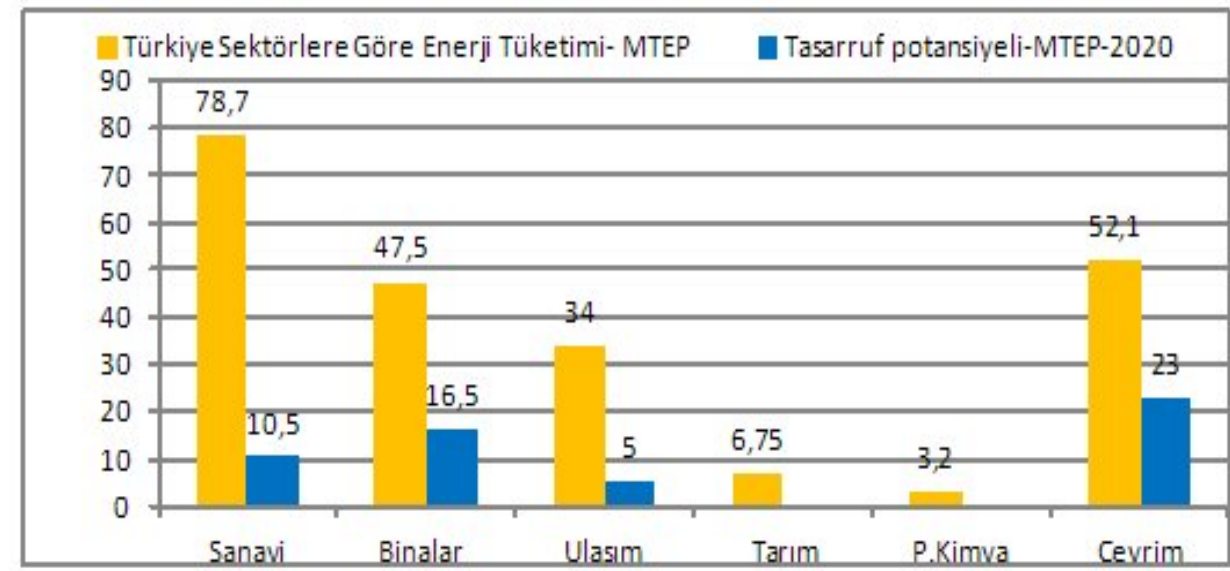

Şekil 2.Türkiye'nin 2020 yılına yönelik sektörlerdeki enerji tasarruf potansiyeli (WWF Enerji İklim Değişikliği 2011).

\section{2. ÇALIŞMANIN ÖNEMI}

Ülkemiz kullandığı enerjinin \%70'e yakın bir bölümünü ithal etmekte ve enerjinin yaklaşık \% 30'u, toplam elektrik tüketiminin ise yaklaşık \% 43'ü konutlarda kullanılmaktadır. Konut sektörü, enerji tüketiminde sanayi sektöründen sonra ikinci sırada yer almaktadır. Dolayısıyla binalarda enerji tasarrufuna yönelik çalışmalar, enerji kaynaklarının etkin kullanımı açısından önemlidir (Narin, Akdemir, 2006, s.8). Ancak, ülkemizde çok sayıdaki eski binanın enerji tasarrufuna yönelik inşa edilmeyişi, hızlı kentleşme olgusuyla yeni binaların enerji verimliliği standartlarına uygun olarak yapılmayışı gibi nedenlerle binalarda enerji kayıpları yüksektir. (Demircan, Uçak, 2009, s.2). Bu nedenle Türkiye gibi enerjisinin çoğunu ithal eden bir ülkede mevcut enerjinin tasarrufu için yapılacak yatırımın, aynı enerjiyi üretmekten çok daha ekonomik olduğu bilinmektedir. Yapılarda tüketilen enerjinin verimli şekilde kullanımı ile ülke ekonomisine katkı sağlanarak çevresel kirliliğe sebep olan fosil kaynaklı yakıtlara gereksinim de azalmaktadır (Kaya, Karakurt, 2018, s.14).

Enerji tüketiminin \%30'u binalar tarafından yapılırken, özellikle binaların enerji performansı ile bağlantılı yapılacak düzenlemeler ile bu tüketimin \%50'ye varan 
oranlarda tasarrufa dönüştürülmesi mümkündür. Türkiye'deki bina sayısının yaklaşık 8,5 milyon olduğu ve bunun \%86'sının konut olduğu göz önüne alınırsa, bahsedilen tasarruf oranının maddi karşıığı yılda 7 milyar dolardır. Bu tasarrufun çevre korumasına ve sürdürülebilir kalkınmaya olduğu kadar, ülke ekonomisine yapacağı katkı da kayda değer miktarda olacaktır (Özyurt, Karabalık, 2009, s.32), (Şekil 3).

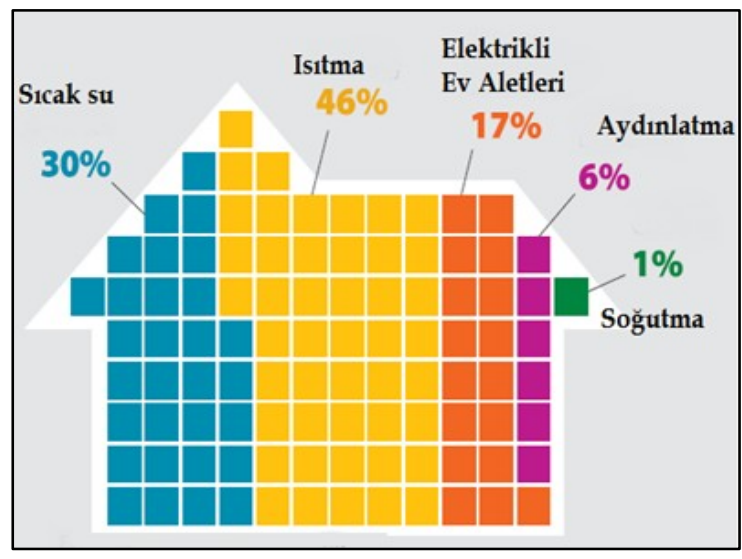

Şekil 3. Konutlarda Enerji Tüketim Oranları (Çakar,2011)

Enerji tasarrufu ve enerjinin verimli kullanımı etkinlikleri ve çalışmaları, yeni ve yenilenebilir teknolojileriyle birlikte, Türkiye'nin gelecekte de en fazla yararlanabileceği politika araçlarının ve teknolojik olanakların başında yer almaktadır. Türkiye'nin enerji tasarrufundan yararlanarak sera gazlarını azaltmaya ve/veya kontrol etmeye yönelik küçümsenmeyecek bir potansiyeli de bulunmaktadır. Enerji tasarrufu çalışmaları, Türkiye'de tüm sektörlerde ortalama \%25'in üzerinde enerji tasarruf potansiyeli bulunduğunu göstermektedir. Ancak öngörülen bu hedeflere ulaşılabilmesi için, belirlenen enerji tasarrufu projelerinin hızlı bir biçimde hayata geçirilmesi, yeni projelerin yapılması ve desteklenmesi gereklidir (Türkeş, 2002,).

Türkiye'nin ikinci en büyük enerji tüketicisi olan bina sektörü ile ilgili son dönemde yapılan araştırmalar, konutlarda tüketilen enerjinin ve karbondioksit emisyon oranının \%30'larda olduğunu göstermektedir. Bu nedenle konutlarda uygulanacak enerji verimliliği çalışmaları oldukça önemlidir (enver.gov.tr, 2018). Binalarda ve sanayi sektöründe enerji tüketimini ve korunumunu hedef alan enerji verimliliği stratejileri ile birlikte enerji verimliliğinin arttırılması, yasal ve kurumsal yapının güçlendirilmesi ve uygulamaların hızlandırılması oldukça önemlidir. Bu çalışmalar kapsamında binalarda enerjinin korunumu, verimli kullanımı ve sera gazı salınımı konularında çeşitli projeler üretilmektedir. Bu projeler ilgili bakanlık, kurum ve kuruluşların işbirliği ile yapılmaktadır. Bu çalışmanın amacı, binalarda enerji tasarrufuna yönelik gerçekleştirilen projelerin değerlendirmesi yapılarak; enerji kaynaklarının etkin kullanımının önemi, yerel yönetimlerin kaynakların dengeli tüketiminde sorumluluk almaları ve kamuoyunda farkındalık bilinci oluşturmaktır.

\section{METOD}

Çalışmada; ülkemizde enerji verimliliği konusunda ilgili kamu kurumları, yerel yönetimlerin ve $A B$ üyesi ülkelerin paydaş olarak yer aldığı altı proje incelenmiştir. 2002-2017 yılları arasında binalarda enerji verimliliğinin artırılmasına yönelik yapılan projeler; amaç, kapsam, katılımcılar, süre ve yapılan çalışmalar başlıkları altında değerlendirilmiştir (Tablo 1). 
Tablo 1.Türkiye'de Binalarda Enerji Verimliliğinin Arttırılması İçin Yapılan Projeler (yegm.gov.tr, eigm.gov.tr, 2018)

\begin{tabular}{|c|c|}
\hline Projenin adı & Binalarda Enerjinin Etkin Kullanımı Projesi: Erzurum İlinde Uygulama \\
\hline Projenin süresi & $01.11 .2002-31.10 .2005$ (3 yıl) \\
\hline Taraflar & $\begin{array}{l}\text { Enerji ve Tabii Kaynaklar Bakanlığı, Elektrik İşleri Genel Müdürlüğü } \\
\text { (ElGM), Erzurum Büyükşehir Belediyesi (EBB), Alman Teknik İşbirliği } \\
\text { Kurumu (GTZ) }\end{array}$ \\
\hline Amaç/ Hedefler & $\begin{array}{l}\text { - Türkiye'de enerjinin verimli kullanılması sağlanarak, büyük oranda } \\
\text { ithal edilen enerji tüketiminin azaltılması, } \\
\text { - Kaynakların dengeli tüketimi ile çevre kirliliğinin azaltıması, } \\
\text { - Yapılacak çalışmalar ile kamuoyunun enerjiyi verimli kullanılma } \\
\text { konusunda bilinçlendirilmesi, } \\
\text { - Alınacak önlemlerle birim alanın veya hacmin ısıtılmasında gerekli } \\
\text { olan enerji intiyacının azaltıması, } \\
\text { - Pilot bölge Erzurum'da yerel bir enerji yönetiminin oluşturulması, } \\
\text { - Isı yalıtımı ve enerjinin etkin kullanımı ile ilgili kanun, yönetmeliklerin } \\
\text { hazırlanması, } \\
\text { - Depreme dayanıklı akıllı yapılar ve standartların geliştirilmesi için } \\
\text { öneriler hazırlanması. }\end{array}$ \\
\hline Yapılan çalışmalar & $\begin{array}{l}\text { - Bina etütleri, eğitim programları, yasal düzenleme ihtiyaçlarının } \\
\text { belirlenmesi, belediyelerde danışmanlık merkezlerinin oluşturulması } \\
\text { - Seçilen mevcut binalarda iyileştirme uygulamaları yapılması, } \\
\text { sonuçlarının izlenmesi deprem hasarı gören binaların hasar } \\
\text { tespitinde bulanık mantık yaklaşımı ve yaygınlaştırılması, } \\
\text { - Bilinçlendirme çalışmaları yapılması. }\end{array}$ \\
\hline Projenin adı & Projesi \\
\hline Projenin süresi & Temmuz 2005-Aralık 2007 (2 yıl) \\
\hline Taraflar & Fransa (ADEME), Hollanda (SENTERNOVEM), EIGM, UETM \\
\hline Amaç/ Hedefler & $\begin{array}{l}\text { - Avrupa Birliği'nin enerji verimliliği politikaları ve uygulamaları } \\
\text { konusunda teknik yardım, bilgi transferi ve eğitim yoluyla Avrupa'daki } \\
\text { benzerlerine uygun bir yapının Türkiye'de oluşturulması, } \\
\text { - Illgili enerji verimliliği mevzuatının gözden geçirilerek ve } \\
\text { değerlendirilerek AB mevzuatına uygun yasal oluşumun } \\
\text { gerçekleştirilebilmesi için tavsiyelerde bulunulması } \\
\text { - Yasal ve kurumsal yapının kuvvetlendirilmesi ve sektörel enerji } \\
\text { tasarrufu potansiyellerinin belirlenmesi faaliyetleri, } \\
\text { - Sanayi, bina ve ulaşım sektörlerinde enerji tasarrufu potansiyelinin } \\
\text { belirlenmesi. }\end{array}$ \\
\hline n çalışmalar & $\begin{array}{l}\text { - Tüm enerji tüketen sektörlerde enerji tasarrufu potansiyelinin } \\
\text { değerlendirilebilmesi için mevcut çalışmaların, etüt sonuçlarının } \\
\text { gözden geçirilmesi, } \\
\text { - Enerji tasarrufu potansiyelleri, indikatörler ve modellemelerle ilgili ElE } \\
\text { ve ilgili kuruluşlardan seçilecek uzman bir kadroya özel bir eğitim } \\
\text { düzenlenmesi, } \\
\text { - ElE/UETM elemanlarının enerji verimliliği stratejisini daha da } \\
\text { geliştirebilmeleri ve çalışmaları yönlendirebilmeleri için eğitim } \\
\text { programları oluşturulması, } \\
\text { - Enerji verimli teknolojileri, know how ve maliyetleri içerecek şekilde } \\
\text { enerji indikatörleri sistemi ve benchmarking veri tabanı oluşturulması, } \\
\text { - Oluşturulacak benchmarking veri tabanı ile bağlantılı olarak enerji } \\
\text { tasarrufu potansiyelinin ve maliyet etkin tedbirlerin alt sektörler }\end{array}$ \\
\hline
\end{tabular}




\begin{tabular}{|c|c|}
\hline & $\begin{array}{l}\text { bazında belirlenmesi, } \\
\text { - Halkın bilincinin arttıııması ve enerji verimli teknolojik bilgilerin } \\
\text { yaygınlaştırılması, kamuoyunun bilinçlendirilmesi ile ilgili bir strateji } \\
\text { geliştirilmesi için destekte bulunulması ve promosyon materyalinin } \\
\text { geliştirilmesi, } \\
\text { - Yerel düzeyde enerji tasarrufu programlarının geliştirilmesi ve } \\
\text { izlenmesi için destek sağlanması, özellikle bina ve ulaşım } \\
\text { sektörlerinde yerel makamların ve paydaşların enerji verimliliği } \\
\text { hakkında bilgilendirilmesi, organize edilmesi ve eğitilmesi. }\end{array}$ \\
\hline Projenin adı & Üçüncü Ülke Eğitim Programı Projesi (JICA) \\
\hline Projenin süresi & 2004-2016 (3 yıl süreli eğitim programları) \\
\hline Taraflar & $\begin{array}{l}\text { Enerji İşleri Genel Müdürlüğü (EIGM), Türk İşbirliği ve Koordinasyon } \\
\text { Ajansı Başkanlığı (TIKA), Japon Uluslararası Koordinasyon Ajansı } \\
\text { (JICA) }\end{array}$ \\
\hline Amaçl Hedefler & $\begin{array}{l}\text { - Enerji verimliliği ve yönetimine dair bilgi ve tecrübelerin paylaşılması } \\
\text { - Katılımcıların, enerji kullanan cihaz ve ekipman, ölçüm cihazları ve } \\
\text { ölçüm metotları hakkında bilgi edinmesi, } \\
\text { - Enerji verimliliği sektörünün teşvik edilmesi ve Türkiye, Japonya ve } \\
\text { katılımcı ülkeler arasında işbirliği kurma imkânlarının geliştirilmesi } \\
\text { - Katılımcılara sanayide ve binalarda enerji verimliliği ve yönetimi ile } \\
\text { ilgili bilgi ve tekniklerini artırma imkânı sağlanması } \\
\text { - CO2 emisyonlarının İklim Değişikliği Sözleşmesi ile öngörülen } \\
\text { sınırlara indirilmesi ve enerjinin verimli kullanılması için teknik gruplar } \\
\text { oluşturulması. }\end{array}$ \\
\hline Yapılan çalışmalar & $\begin{array}{l}\text { - Her yıl iki hafta süreli uluslararası enerji yöneticisi kursları } \\
\text { düzenlenmesi, } \\
\text { - Enerji verimliliği etüt tekniklerinin ve uygulanabilir enerji maliyetini } \\
\text { azaltma fırsatlarının belirlemesi ve gerçekleştirilmesi, } \\
\text { - YEGM ve özel sektörden katılan uzmanlar tarafından Sanayide } \\
\text { Enerji Verimliliği ve Yönetimi Eğitiminde; Elektrik ve Isının Verimli } \\
\text { Kullanımı, Enerji Verimliliği ve Çevresel Etkileri, Aydınlatmada Enerji } \\
\text { Verimliliği, Buhar Sistemlerinde Enerji Verimliliği, Sıkıştırılmış Hava } \\
\text { Sistemleri ve Termal Yalıtım Ölçüm Ekipmanı ve Teknikleri, } \\
\text { Pompalama Sistemlerinde Enerji Verimliliği ve Yatırımların Ekonomik } \\
\text { Analizi konularında eğitim seminerlerinin verilmesi, } \\
\text { - Bölge ve komşu ülke mühendislerinin enerji verimiliği ve yönetimine } \\
\text { dair bilgi ve tecrübelerin paylaşılması. }\end{array}$ \\
\hline Projenin adı & $\begin{array}{l}\text { Türkiye'de Enerji Verimliliği İzleme ve Değerlendirmesinin } \\
\text { Geliştirilmesi Projesi }\end{array}$ \\
\hline Projenin & Ocak 2011-Ocak 2013 ( 2yıl) \\
\hline Tara & Hollanda Ekonomik İşler Bakanlığı, NL Ajansı, Türkiye EIGM \\
\hline Amaçl Hedefler & $\begin{array}{l}\text { - Enerji verimliliği programlarının izlenmesi ve değerlendirilmesi } \\
\text { konularında bilgi birikimi sağlama, } \\
\text { - Enerji tasarrufu potansiyellerinin hesaplanma yöntemlerinin } \\
\text { geliştirilmesi, } \\
\text { - Enerji verimliliği politikalarının etkilerinin değerlendirilmesi yöntemleri } \\
\text { ve öncelikli sektörlerde pilot uygulamalar gerçekleştirilmesi. }\end{array}$ \\
\hline Yapılan çalışmalar & $\begin{array}{l}\text { - Uzmanlık kapasitesinin geliştirilmesi, } \\
\text { - Pilot proje uygulamaları, izleme ve değerlendirme ile ilgili yöntemlerin } \\
\text { geliştirilmesi gibi faaliyetlerle izleme ve değerlendirme çalışmalarına } \\
\text { destek sağlanması. }\end{array}$ \\
\hline & \\
\hline Projenin süresi & 2011- \\
\hline
\end{tabular}




\begin{tabular}{|c|c|}
\hline Taraflar & $\begin{array}{l}\text { Çevre ve Şehircilik Bakanlığı, Milli Eğitim Bakanlığı, Birleşmiş Milletler } \\
\text { Kalkınma Programı (UNDP) IGEF }\end{array}$ \\
\hline Amaç/ Hedefler & $\begin{array}{l}\text { - Bina sektöründe enerji verimliliğinin artırılması, } \\
\text { - Yeni binalarda ısıtma ve soğutma için hesaplama yöntemlerinin } \\
\text { bütünleşik bina tasarımı yaklaşımıyla ilişkilendirilerek geliştirilmesi, } \\
\text { - Binalarda enerji verimliliği ve yenilenebilir enerji teşvikleri için finansal } \\
\text { mekanizma önerileri geliştirilmesi } \\
\text { - Binalarda enerji kullanımı ile ilgili mevzuatın güçlendirilmesi. }\end{array}$ \\
\hline Yapılan çalışmalar & $\begin{array}{l}\text { - Ülke şartlarına uygun bina tasarım kriterlerinin geliştirilmesi, } \\
\text { - Yaklaşık sıfı enerjili bina uygulamaları için bir yol haritası } \\
\text { oluşturulması, } \\
\text { - En az \%50 enerji tasarrufu sağlayan enerji verimli örnek bina } \\
\text { uygulamaları, } \\
\text { - Sektörde etkili aktörlere yönelik kapasite geliştirme programlarının } \\
\text { geliştirilerek uygulanması. }\end{array}$ \\
\hline Projenin adı & Binalarda Enerj \\
\hline Projenin süresi & Nisan 2015-Nisan 2017 (2 yıl) \\
\hline Taraflar & $\begin{array}{l}\text { Çevre ve Şehircilik Bakanlığı, NIRAS IC Sp. Z.o.o. (Polonya) } \\
\text { liderliğindeki Energy Saving International AS (Norveç), Danish } \\
\text { Technological Institute (Danimarka) ve Rast Mühendislik Hizmetleri } \\
\text { Ltd. Sti. (Türkiye) firmalarından oluşan Konsorsiyum }\end{array}$ \\
\hline Amaç/ Hedefler & $\begin{array}{l}\text { - Türkiye'deki mevcut ve yeni binaların enerji verimliliğini konu alan } \\
\text { mevzuat ve kurumsal çerçeveye ilişkin boşluk ve ihtiyaçların ele } \\
\text { alınması, } \\
\text { - Mevzuatı ve kurumsal çerçeveyi, Avrupa'da uygulamaya konulan en } \\
\text { yeni politika ve direktiflerle, özellikle de } 2010 \text { yılında yayınlanan } \\
\text { Binalarda Enerji Performansı Direktifi (EPBD) ile uyumlu hale } \\
\text { getirilmesi, } \\
\text { - Bina Enerji Performansı'nın (BEP) uygulanmasını destekleyecek } \\
\text { insan kaynakları stratejisinin geliştirilmesi. }\end{array}$ \\
\hline Yapılan çalışmalar & $\begin{array}{l}\text { - Türkiye'de Binaların Enerji Verimliliğiyle ilgili mevcut durumun } \\
\text { incelenmesi, } \\
\text { - BEP'in iyileştirilmesine yönelik bir stratejinin hazırlanması, } \\
\text { - Kilit ortaklarla (Bakanlıklar, Bankalar, Kamu Kurumları, Belediyeler, } \\
\text { vb.) işbirliklerinin geliştirilmesi, } \\
\text { - Bina tipolojileri ile ilgili tanımların geliştirilmesi ve bir bina veri } \\
\text { envanterinin oluşturulması, } \\
\text { - Binaların yaşam süreleri boyunca sergileyecekleri enerji } \\
\text { performansını ekonomik açıdan değerlendirmek üzere basit bir enerji } \\
\text { performansı simülasyon aracının geliştirilmesi, } \\
\text { - Binalarda enerji verimliliği konusunda çalıştayların, eğitimlerin, } \\
\text { bölgesel seminerlerin ve çalışma ziyaretlerinin düzenlenmesi, } \\
\text { uluslararası konferanslara katıım sağlanması, } \\
\text { - Enerji tasarrufu sağlayacak yollar hakkında araştırma yürütülmesi ve } \\
\text { mali destek sağlayacak kaynakların belirlenmesi, } \\
\text { - Mimarlık ve mühendislik öğrencileri arasında binalarda enerji } \\
\text { verimliliği konulu bir yarışma düzenlenmesi. }\end{array}$ \\
\hline
\end{tabular}

\section{DEĞERLENDIRME}

Bu çalışmada enerji yönetim bilinci oluşturmak için iş bölümü ile resmi kurumlarda ve özel sektörde enerjinin korunumu ve verimli tüketiminin oluşturulması amacı ile binalarda enerji verimliliğinin arttırılmasına yönelik gerçekleştirilen projeler incelenmiştir. Projeler genel olarak incelendiğinde, yapılan çalışmaları iki başlık altında değerlendirebiliriz: 
- Eğitim Çalışmaları

Kamu ve özel sektörün bilinçlendirilmesi amacıyla verilen eğitim seminerleri, konferanslar ve enerji performansı konusunda uzman kişilerin yetiştirilmesi projelerin hepsinde planlanan çalışmalardır. Ayrıca okullarda enerji verimliliğine yönelik yapılan uygulamalar (yarışma, proje vb.) ile duyarlılık ve farkındalık bilinci oluşturulmuştur. Binalarda Enerji Verimliliğinin Arttırıması için Teknik Yardım Projesi kapsamında binalarda enerji verimliliği ve alt başlıklarını içeren eğitim rehberleri oluşturulmuştur.

Projelerde verilen eğitimlerle birlikte, enerji verimliliğine ilişkin yöntem ve davranış şekillerini, toplumun her kesiminde farklı çalışma/yaşam alanlarında geliştirmek ve uygulamak amaçlanmıştır.

- Etüd Proje Çalışmaları

Eğitim programlarını içeren projeler dışında yer alan diğer projelerin ana hedefleri, kamu ve konut binalarının enerji performanslarının arttırıması için yapılan etüd ve uygulama çalışmalarıdır. Bu kapsamda; Binalarda Enerjinin Etkin Kullanımı Projesi: Erzurum İlinde Uygulama projesinde örnek konut binalarının enerji tüketimleri, ısı kayıplarının analizleri ve ölçümler yapılmıştır. Proje kapsamında 4 örnek proje etüd edilmiş, uygulanmış ve sonuçları izlenmiştir. $\mathrm{Bu}$ analizler sonucunda binaların enerji performanslarının arttırılmasına yönelik iyileştirmeler ortaya konmuştur (Tablo 2).

Tablo 2. Proje kapsamında enerji iyileştirilmesi yapılan binalar (Erzurum Enerji Danışmanlık Merkezi, 2006)

\begin{tabular}{|l|l|l|}
\hline Proje & Değerlendirme \\
\hline $\begin{array}{l}\text { Erzurum Atatürk } \\
\text { Üniversitesi 30. } \\
\text { Lojmanı }\end{array}$ & $\begin{array}{l}\text { Ölçülen tasarruf oranı \% 51,7 } \\
\text { Dış cephe ısı yalıımı, ek çatı } \\
\text { yalıtımı, termostatı vana ve } \\
\text { otomatik kontrol sistemi } \\
\text { uygulanmıştır. }\end{array}$ \\
\hline $\begin{array}{l}\text { Dilek Ailesi Müstakil } \\
\text { Evi, Erzurum }\end{array}$ & $\begin{array}{l}\text { Hesaplanan tasarruf oranı: \% 37 } \\
\text { Dış cephe ISı yalıtımı uygulaması } \\
\text { yapılmıştır. }\end{array}$ \\
\hline $\begin{array}{l}\text { Cansever Yapı } \\
\text { Kooperatifi, Erzurum }\end{array}$ & $\begin{array}{l}\text { Hesaplanan tasarruf oranı:\%35 } \\
\text { Dış cephe ISı yalıtımı uygulaması } \\
\text { yapılmıstır. }\end{array}$ \\
\hline
\end{tabular}




\begin{tabular}{|l|l|l|}
\hline $\begin{array}{l}\text { Hesaplanan tasarruf oranı:\% } 50 \\
\text { Dış duvarlar ve çatıda yalıtım, } \\
\text { termostatik radyatör vanaların } \\
\text { montajı ve pencerelerin iki yüzlü } \\
\text { Yetiştirme Yurdu }\end{array}$ & PVC kaplaması yapılmıştır. \\
&
\end{tabular}

Binalarda Enerji Verimliliğinin Artırılması Projesi kapsamında iki pilot proje gerçekleştirilmiştir. Projelerden biri, Bütünleşik Bina Tasarımı Yaklaşımı ile tasarımı ve yapımı gerçekleştirilen Türkiye'nin ilk yeşil kamu binası olan Eryaman Cezeri Yeşil Teknoloji Teknik Meslek ve Endüstri Meslek Lisesi'dir. Yapımı devam etmekte olan diğer proje ise Çevre ve Şehircilik Bakanlığı'na bağlı Tapu ve Kadastro Genel Müdürlüğü Hizmet Binasıdır. Proje kapsamında ülkemizdeki binaların bölgelere göre minimum enerji performanslarını gösteren sekiz bina tipolojisi belirlenmiştir. Bu tipolojilere göre, minimum bina enerji performans standartları içinde binaların en fazla tüketebileceği enerji miktarlarının sınıflandırması yapılmıştır,(Tablo 3), (yapi.com.tr,2019).

Tablo 3. Proje kapsamında yapılan enerji etkin binalar (yem.gov.tr, 2019)

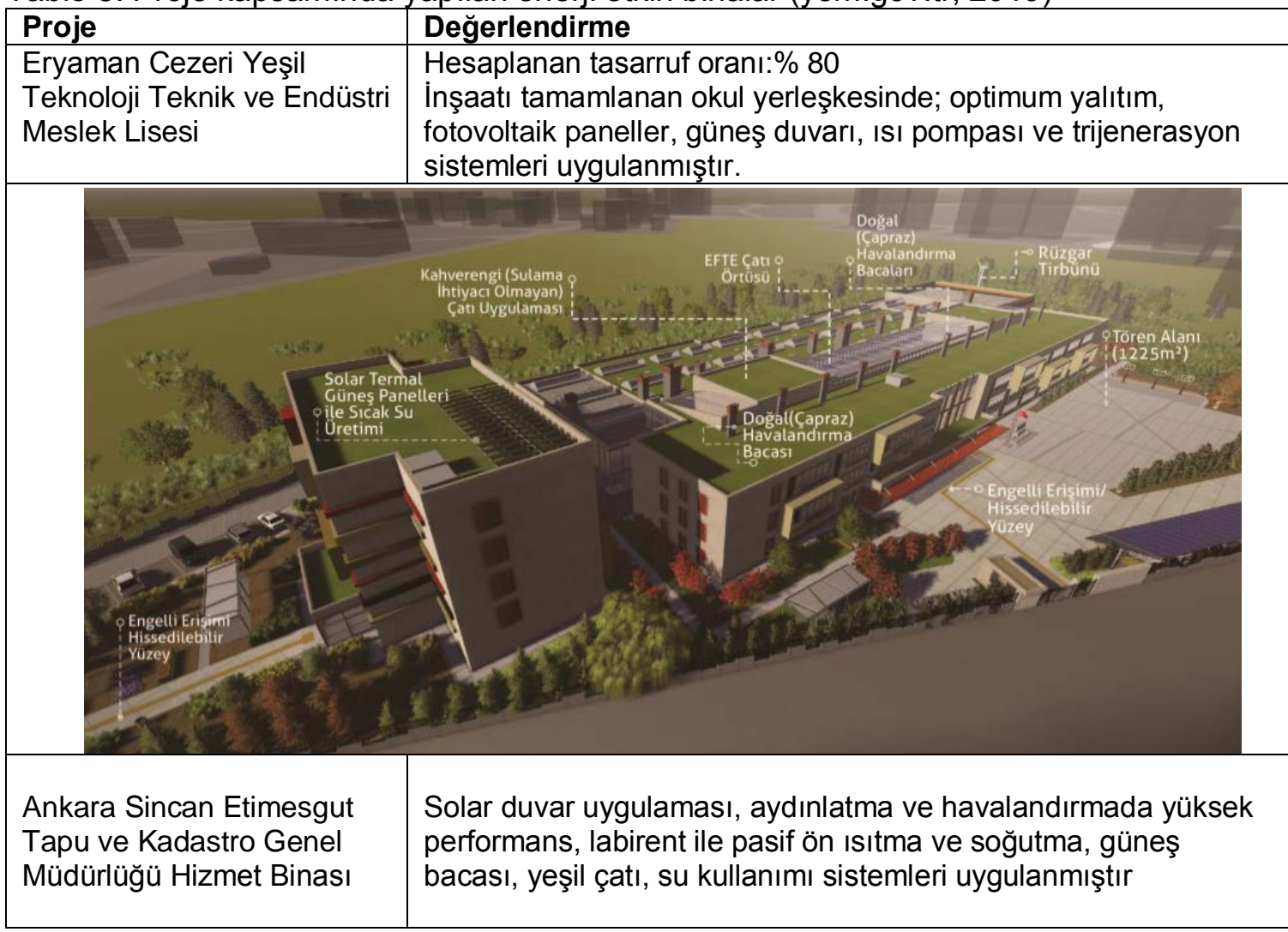




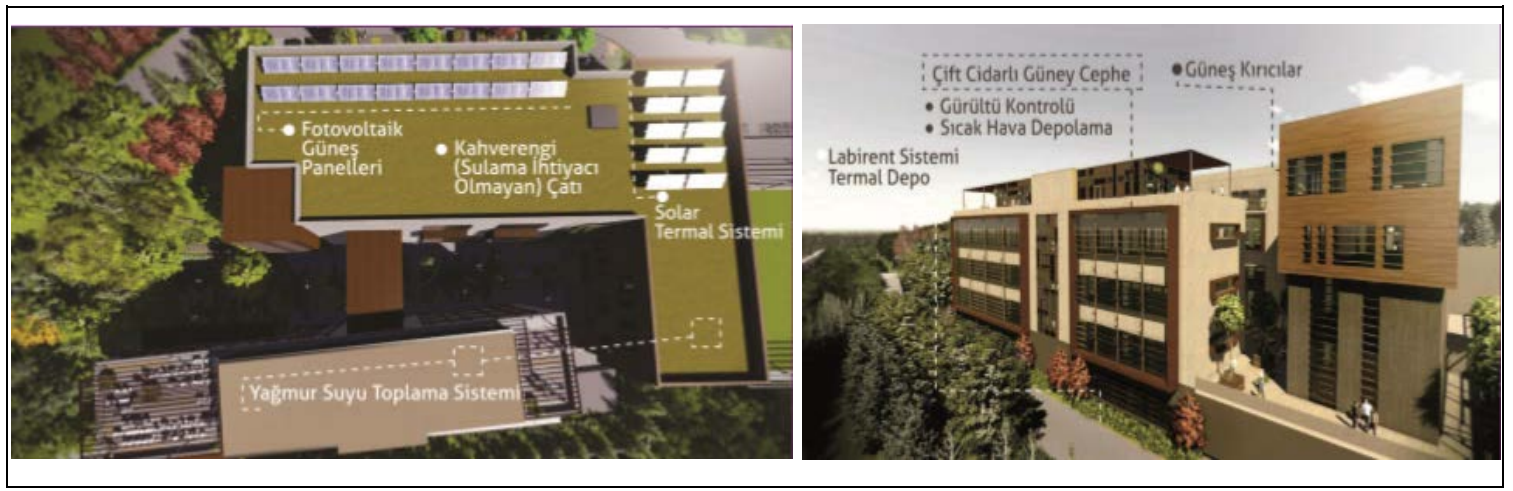

Binalarda Enerji Verimliliğinin Arttıııması için Teknik Yardım Projesi kapsamında dört iklim bölgesinde yer alan Adana, Samsun, Ankara ve Erzurum illerinde benzer özelliklerde konut ve ofis binalarının enerji performansları incelenerek etüd ve fizibilite çalışmaları yapılmıştır (Tablo 4). Bu fizibilite çalışmalarını, enerji verimliliği önlemleri ve yenileme paketleri oluşturmaktadır. Yapılan çalışmalar ile farklı iklim bölgelerinde yer alan farklı tipteki binaların yenilenmesinde uygulanabilecek enerji verimliliği iyileştirmeleri ve çevresel etkilerin neler olduğu açıklanmıştır.

Tablo 4. Proje kapsamında enerji iyileştirilmesi yapılan binalar (Bölgesel seminer sunumu, 2016)

\begin{tabular}{|l|l|l|}
\hline Proje & Değerlendirme \\
\hline $\begin{array}{l}\text { 2. İklim Bölgesinde yer alan } \\
\text { Samsun ilinde örnek ofis } \\
\text { binası }\end{array}$ & $\begin{array}{l}\text { Hesaplanan tasarruf oranı } \\
\text { ortalama:\% 60 } \\
\text { Ilave duvar ve çatı yalıtımı, } \\
\text { kapı pencere değişiklikleri, } \\
\text { Isıtma sisteminde değişiklik, ısı } \\
\text { pompası, gölgeleme } \\
\text { elemanları önerilmiştir. }\end{array}$ \\
\hline $\begin{array}{l}\text { 3. İklim Bölgesinde yer alan } \\
\text { Ankara ilinde örnek konut } \\
\text { binası }\end{array}$ & $\begin{array}{l}\text { Hesaplanan tasarruf oranı } \\
\text { ortalama:\%55 } \\
\text { Ilave duvar ve çatı yalıtımı, } \\
\text { kapı pencere değişiklikleri, } \\
\text { Isıtma sisteminde değişiklik, ısı } \\
\text { pompası önerilmiştir. }\end{array}$ \\
\hline
\end{tabular}

Bu bağlamda ülkemizde Enerji Verimliliği Kanunu ile birlikte, binalarda enerjinin verimli kullanımı ve tasarruf önlemleri kapsamında birçok önemli proje yapılmakta olup bunların sonuçlarının dikkate alınarak bu bilincin sürekliliği sağlanmalıdır. Yapılan proje çalışmalarında ana hedef, binalarda enerjinin etkin kullanılması ile yerel kaynakların korunması, ithal enerji talebinin düşürülmesi ve buna bağlı olarak daha az yakıt tüketilmesi ile zararlı emisyonların çevreye olumsuz etkilerinin azaltılması olmuştur. 


\section{SONUÇLAR}

Türkiye'de 2005 yılından bu yana Avrupa Birliği ile uyum süreci çerçevesinde binalarda enerjinin etkin ve verimli kullanımı konusunda çeşitli yasal düzenlemeler, standartlar ve yenilenebilir enerji kaynaklarının kullanımına ilişkin yönetmelikler uygulanmaya başlanmıştır. Çalışmada incelenen projeler; enerji verimliliği ile ilgili yeterli bilincin oluşması ve enerjinin önemine dikkat çekmek için kamu, özel sektör ve yerel yönetimlerin yapacakları faaliyetler çerçevesinde gerçekleştirilmiştir. Buna göre projelerin değerlendirmesi yapıldığında pratikte yarar sağlayacağı sonuçlar şunlardır:

- Ulusal düzeyde enerji politikalarının geliştirilmesi, kurumsal ve yasal yapının güçlendirilmesi,

- Binaların enerji performanslarının arttırıması ve enerjinin korunumu,

- Yenilenebilir enerji kaynaklarının kullanımı,

- Bütünleşik tasarım yaklaşımı,

- İlgili standartların revize edilmesi,

- Enerji performansı hesaplama programlarının geliştirilmesi,

- Kontrol ve denetim mekanizmalarının işleyişinin önemi,

- Halkın enerji tüketimi ve enerji verimliliği konusunda bilinçlendirilmesi, eğitilmesi

- Bilgi ve uzman eksikliğinin giderilmesi,

- Enerji danışmanlık hizmetlerinin ilgili sektörlerde ele alınmasıdır.

Tüm bu çalışmalar, hem enerji verimliliğini sağlama hem de binaların ürettiği sera gazı salınımlarını azaltmada ulusal ve uluslararası düzeyde hedeflere ulaşmada büyük ve önemli katkılar sağlamaktadır. Bu bağlamda özellikle enerji performansları düşük olan kamu ve konut binalarının enerji iyileştirmelerinin yapılması ve yeni binalarda da yüksek enerji performansına sahip sistemlerin uygulanması enerji verimliliği açısından oldukça önemlidir. 


\section{KAYNAKLAR}

Al-Homoud, M.,S., Computer Aided Building Energy Analysis Techniques, Building and Environment, Vol.36, 2001, s.421-433.

Binalarda Enerji Verimliliğinin Teşviki, Proje Sonuçları Kataloğu, Erzurum Enerji Danışmanlık Merkezi, 2006, s.8,26.

Binalarda Enerji Verimliliğinin Arttırıması için Teknik Yardım Projesi, Bölgesel Seminer Sunumları, Trabzon, 2016.

Çakar, E., A., Binalarda Enerji Verimliliğinin Arttırılmasındaki Mevcut Dar Boğazlar,2011,

http://www1.mmo.org.tr/resimler/dosya_ekler/caafdb46f3fec7b_ek.pdf?tipi=68\&turu=X\& sube=2, 23.05.2019.

Demircan, N., Uçak, S., Türkiye'de Enerji Verimliliği ve Tasarruf Potansiyeli, III. Enerji Verimliliği ve Kalitesi Sempozyumu,2009,s.3.

http://www.emo.org.tr/ekler/33c967a129a4a6f_ek.pdf, 02.11.2018.

Directive 2010/31/EU, Directive of the European Parliament and of the Council of 19 May 2010 on the Energy Performance of Buildings (recast), 2010.

Directive 2002/91/EC, Directive of the European Parliament and of the Council of 16 December 2002 on the Energy Performance of Buildings, 2002.

Doğan, H., Yılankıran, N., Türkiye'nin Enerji Verimliliği Potansiyeli ve Projeksiyonu, Gazi Üniversitesi Fen Bilimleri Dergisi Part:C, Tasarım ve Teknoloji GU J SCI Part:C 3(1), 2015, s.375-383.

Enerji Verimliliği Kanunu, www.mevzuat.gov.tr/MevzuatMetin/1.5.5627.doc., 24.11.2018.

Kavak, K., "Dünya ve Türkiye'de Enerji Verimliliği ve Türk Sanayiinde Enerji Verimliliğinin İncelenmesi”, Uzmanlık Tezi, DPT, İdari Sektörler ve Koordinasyon Genel Müdürlüğü, Yayın No:2689, Ankara, 2005, s.5.

Kaya, T., Karakurt, C., Tuğla Duvarlarda Uygulanan Sıvaların Enerji Verimliliğinin Değerlendirilmesi, Eskişehir Osmangazi Üniversitesi Mühendislik ve Mimarlık Fakültesi Dergisi 26(1), 2018, S:14-19.

Keskin, T., Türkiye'nin Enerji Verimliliği Politikası, Programları,2011. https://www.mmo.org.tr/sites/default/files/gonderi_dosya_ekleri/tulinkeskinsunum.pdf, 29.11. 2018.

Narin, M., Akdemir, S., Enerji Verimliliği ve Türkiye, Türkiye Ekonomik Kurumu, UEKTEK, 2006, s.8.

$\begin{array}{llll}\text { Onuncu Kalkınma } & \text { Planı } & \text { (2014-2018), } & \text { s.198. }\end{array}$ www.resmigazete.gov.tr/eskiler/2013/07/20130706m1-1-1.doc, 02.01.2019.

Özyurt, G., Karabalık, K., Enerji Verimliliği, Binaların Enerji Performansı ve Türkiye'deki Durum, Türkiye Mühendislik Haberleri Dergisi, Sayı 457, 2009, S:32-34. 
Sağlam, G.,N., Yılmaz, Z., (2015), Avrupa Birliği Direktifi Doğrultusunda Binalarda Yaklaşık Sıfır Enerji Düzeyinin Akdeniz Ülkesi Olan Türkiye'de Konut Binaları İçin Belirlenmesine Yönelik Uygulama Örneği, 12.Ulusal Tesisat Mühendisliği Kongresi, Bildiriler Kitabı, Cilt 2, 2015, İzmir, S.:1267-1281.

Türkeş, M., İklim Değişikliği ve Sürdürülebilir Kalkınma Ulusal Değerlendirme Raporu, Türkiye Teknoloji Geliştirme Vakfı, 2002, Ankara.

Türkiye'de Binalarda Enerji Verimliliğinin Artırılması Projesi, 2017, www.yegm.gov.tr 30.05.2019.

Türkiye'nin Enerji Verimliliği Haritası ve Hedefler Raporu, 2012, http://www.enver.org.tr/UserFiles/Article/90dfee6d-4004-4165-99c0-5642a4e90ed0.pdf, 10.12.2018

www.yapi.com.tr/haberler/turkiyede-binalarda-enerji-verimliliginin-artirilmasi-projesi, 30.05.2019

www.yegm.gov.tr,17.4.2018.

WWF Enerji İklim Değişikliği 2011, https://www.enerjivetesisat.com/enerji/verimlilik/3613-tuerkyede-enerj-vermll-cokun karabal-enve-enerji, 25.05.2019. 